\title{
Geneza i ewolucja pojęcia przedsiębiorczości
}

DOI: $10.47050 / 65591760.36-48$

Piotr Komraus

W rozdziale przedstawiony został proces ewolucji pojęć przedsiębiorcy i przedsiębiorczości w myśli ekonomicznej. Wskazane zostały podstawowe nurty w sposobie postrzegania roli i znaczenia przedsiębiorczości dla wzrostu oraz rozwoju gospodarczego. W oparciu o wskazane kryteria wyróżniono pięć głównych podejść w definiowaniu analizowanych pojęć. Scharakteryzowany został dorobek wybranych ekonomistów reprezentujących poszczególne podejścia. Podjęta została także próba określenia kierunku ewolucji przedsiębiorczości w przyszłości.

\section{Słowa kluczowe:}

przedsiębiorczość

przedsiębiorca

historia myśli ekonomicznej

rozwój gospodarczy 


\section{The genesis and evolution of the notion of entrepreneurship}

DOI: $10.47050 / 65591760.36-48$

Piotr Komraus

This chapter presents the process of evolution of the notions of an entrepreneur and entrepreneurship in economic thought. Two basic trends in the way of perceiving the role and significance of entrepreneurship for the economic growth and development have been depicted. On the basis of the indicated criteria five main attitudes towards defining the analyzed notions have been differentiated. The output of some selected economists representing particular attitudes has been presented. The attempt to determine the direction of the evolution of entrepreneurship in the future has also been made.

Keywords:

entrepreneurship

entrepreneur

history of economic thought

economic growth 


\section{Wstęp}

W okresie przed rewolucją przemysłową przedsiębiorczość stanowiła cechę człowieka wyrażającą się działalnością ukierunkowaną na zaspokajanie potrzeb. Naturalne poczucie braku czegoś wymuszało podejmowanie zróżnicowanych form aktywności na rzecz jego zaspokojenia. Nowy wymiar pojęcia przedsiębiorczości pozostaje ściśle związany z rewolucją przemysłową i przekształceniami procesów gospodarowania oraz procesów społecznych. Pojęcie podlega ewolucji w ramach powstających nurtów myśli ekonomicznej. Rozpatrywane jest także w ujęciu psychologicznym, socjologicznym, antropologicznym i kulturowym.

Wskazania wymaga podstawowa różnica $w$ definiowaniu przedsiębiorczości przez ekonomię i pozostałe nauki społeczne. W podejściu ekonomicznym przedsiębiorczość i przedsiębiorcę określa rola pełniona w mechanizmie gospodarczym. Ujęcie psychologiczne, społeczne, kulturowe postrzega przedsiębiorczość jako zespół postaw (o komponentach: emocjonalnym - nastroje i uczucia, behawioralnym - predyspozycje do zachowań i poznawczym) oraz zachowań (intencje, sposobność prowadzenia aktywności gospodarczej) jednostki i społeczeństwa wpływających na kształtowanie własnej przyszłości (Białasiewicz 2008, s. 9).

\section{Przedsiębiorczość w teorii ekonomii - rys historyczny}

Teorię ekonomii charakteryzuje zróżnicowane podejście w ocenie znaczenia przedsiębiorczości dla rozwoju społeczno-gospodarczego. Podstawowym podziałem - w przedmiotowym zakresie - myśli ekonomicznej jest podział na nurt wskazujący przedsiębiorczość jako czynnik rozwoju gospodarczego oraz nurt zagadnienie pomijający. Pierwszy z wyszczególnionych nurtów tworzą m.in. R. Cantillon, fizjokraci z F. Quesnayem, A. Smith, J.B. Say, szkoła schumpeterowska, szkoła austriacka oraz w ramach szkoły chicagowskiej -F. Knight. Ograniczoną rolę w pobudzaniu rozwoju społeczno-gospodarczego przedsiębiorczości przypisuje keynesizm. Zagadnienie przedsiębiorczości pozostaje natomiast niedostrzegane przez:

1. Psychologiczne aspekty przedsiębiorczości, „Forum Współpracy Małego i Dużego Biznesu”, forumbiznesu-zpp.pl/aktualnosci/psychologiczne-aspekty-przedsiebiorczosci (dostęp 30.11.2018). 
$\rightarrow$ ekonomię klasyczną i neoklasyczną (wyjątkami wśród ekonomistów klasycznych są A. Smith i J.B. Say oraz w zakresie ekonomii neoklasycznej - szkoła austriacka),

$\rightarrow$ marksizm uznający klasę robotniczą za podstawową siłę zmian i postrzegający rozwój jako wynik zarówno determinizmu, jak i dialektyki.

Przeprowadzone studia literaturowe pozwoliły na wyodrębnienie w ramach nurtu afirmującego rolę przedsiębiorczości pięciu kryteriów definiujących pojęcia przedsiębiorcy i przedsiębiorczości. Kryteriami powyższymi są: niepewność, pełniona funkcja dostawcy kapitału, zorientowanie na zysk, umiejętność tworzenia i forma zarządzania organizacją oraz innowacyjność. Proces wskazywania kryteriów wyraża ewolucję pojęcia przedsiębiorczości w myśli ekonomicznej.

Podejście definiujące przedsiębiorczość jako funkcję niepewności zainicjowane zostało na początku XVIII w. przez R. Cantillona. Rozwinięcie podejścia zawierają prace m.in. J.B. Saya, H.K. von Mangoldta, L. von Misesa oraz F. Knighta. Wkładem R. Cantillona w myśl ekonomiczną jest wyróżnienie i analiza pojęcia przedsiębiorcy (Rothbard 2011) oraz jego roli i znaczenia w gospodarce. W pracy Essay on the nature of trade in general R. Cantillon (1959) przedstawia szczegółową analizę procesów rynkowych w aspekcie problemu równowagi rynkowej i wszechobecnej niepewności, wskazuje pożądane zachowania podmiotów uczestniczących w procesach rynkowych, analizuje różnice wartości wykonywanej pracy, poszukuje uzasadnienia dla istnienia przedsiębiorców, jak również wskazuje ich funkcje w mechanizmie rynkowym. Kryterium wyróżniającym przedsiębiorców jest kryterium niepewności uzyskiwanych dochodów. Podejście to wywierało istotny wpływ na definiowanie przedsiębiorcy do lat 20. XX w. i prac F. Knighta (Hebert, Link 2011). Społeczeństwo dzieli on na przedsiębiorców oraz ludzi zatrudnionych. Zatrudnieni, bez względu na charakter wykonywanej pracy, stanowią grupę o ograniczonej, w okresie zatrudnienia, niepewności i określonych dochodach. Przedsiębiorców charakteryzuje szeroko postrzegana niepewność, w tym niepewność uzyskiwanych dochodów. Pojęcie przedsiębiorcy jest traktowane bardzo szeroko i w istocie obejmuje każdego, kto podejmuje aktywność gospodarczą w warunkach niepewności (w tym także żebraków). Bogactwo wszystkich mieszkańców pochodzi z własności posiadaczy ziemskich i wszyscy są od nich zależni 
(Cantillon 1959). „Zadaniem biznesmena i przedsiębiorcy jest stanąć naprzeciw i sprostać niepewności poprzez inwestowanie i opłacanie kosztów z nadzieją na zysk². Sklepikarze i kupcy detaliczni wszelkich rzeczy są przedsiębiorcami, którzy kupują rzeczy po określonej cenie i sprzedają w swoich sklepach lub na rynkach po cenie niepewnej. Tym, co zachęca i utrzymuje przedsiębiorców w danym państwie, są konsumenci, którzy będąc ich klientami, wolą płacić nieco więcej, aby otrzymywać to, czego potrzebują do użycia w małych ilościach, w porównaniu z tym, co jest w magazynach, i większość z nich nie ma wystarczających środków, aby kupować z pierwszej ręki" (Cantillon 1959). Przedsiębiorcy pełnią funkcję równoważącą. Poprzez przewidywanie i inwestowanie zasobów na przyszłość przedsiębiorcy pomagają dopasować oraz zbalansować dostawy i popyt (Rothbard 2011).

Przedsiębiorcę w podejściu J.B. Saya wyróżniają zaangażowanie w proces produkcyjny oraz niepewność co do efektu podejmowanych działań. Przedsiębiorcy prowadzą działalność we wszystkich gałęziach gospodarki. Przedsiębiorcami są: rolnicy, rękodzielnicy, kupcy. Przedsiębiorca "współdziała w produkcji, oddając na jej usługi wiedzę, kapitały, umiejętne wykorzystanie czynników naturalnych w celu wytwarzania produktów, do których ludzie przywiązują wartość". Podstawowym wyzwaniem dla przedsiębiorcy jest wytworzenie produktów wartych „przynajmniej tyle lub więcej co koszty produkcji". J.B. Say dokonuje wyraźnego rozróżnienia pomiędzy przedsiębiorcą a kapitalistą. Przedsiębiorca nie musi być kapitalistą. „Przedsiębiorcy są kapitalistami tylko wtedy, kiedy zaangażowany kapitał lub jego część stanowią ich własność" (Say 1960, s. 890). Kapitalista jest posiadaczem kapitału i czerpie z niego zyski, wykorzystując go we własnej pracy lub uzyskując od niego procent (Say 1960, s. 869).

H.K. von Mangoldt tytuł przedsiębiorcy przypisuje podmiotowi posiadającemu prawo do efektów produkcji i kontroli produktu, a jednocześnie ponoszącemu odpowiedzialność za wszelkie straty. Odrzuca podejście definiujące przedsiębiorcę jako osobę angażującą się i nadzorującą proces produkcji, wskazując, że czynności te mogą być efektywnie wypełniane także przez płatną siłę roboczą. Ryzyko przedsiębiorcy wyznacza charakter realizowanej produkcji. Wysokim ryzykiem 
obciążona jest produkcja na rynek. Za bezpieczną uznaje produkcję na zamówienie, w której wyeliminowany zostaje czynnik ryzyka (Hebert, Link 2011). L. von Mises zrównuje pojęcie przedsiębiorczości i spekulacji. Niepewność jest cechą każdego ludzkiego działania i każde działanie jest formą spekulacji. W konsekwencji wszyscy ludzie (także pracownicy), pragnąc wykorzystywać swoje zasoby i umiejętności w celu osiągnięcia zysku, są przedsiębiorcami (Butler 2010). F. Knight w książce Risk, Uncertainty and Profit wskazuje, że w warunkach braku niepewności energia człowieka byłaby w całości poświęcona produkcji. Wątpliwe jest, czy w takiej sytuacji istniałaby inteligencja. W warunkach niepewności produkcja rzeczy, faktyczne wykonywanie czynności, staje się zadaniem wtórnym. Głównym problemem i funkcją organizacji jest wskazywanie, co należy zrobić i jak to zrobić (Knight 1964).

Reprezentantem podejścia definiującego przedsiębiorczość zgodnie z kryterium zorientowania na zysk jest J.M. Keynes. Keynesizm jako nurt w myśli ekonomicznej wyraża ograniczone zainteresowanie problematyką przedsiębiorczości, będące następstwem wielkiego kryzysu, podważonego zaufania do systemu kapitalistycznego i poszukiwania możliwości oraz narzędzi przeciwdziałania kryzysom. Istotę keynesizmu wyraża „teza o możliwości istnienia bezkryzysowego kapitalizmu, kierowanego przez państwo w interesie całego społeczeństwa ku ogólnemu dobrobytowi" (Keynes 2003, s. IX). Dominująca rola państwa w kształtowaniu wzrostu i rozwoju gospodarczego spycha znaczenie przedsiębiorczości na dalszy plan. „Schorzenia kapitalizmu są możliwe do wyleczenia tylko przez zastosowanie środków, które albo są dla społeczeństwa nie do przyjęcia (zbrojenia, wojna), albo wymagają ograniczenia wszechwładzy kapitału" (Keynes 2003, s. IX). Przedsiębiorczość przez J.M. Keynesa definiowana jest jako działalność polegająca "na określaniu przewidywanego dochodu z obiektów kapitałowych w ciągu całego ich trwania" (Keynes 2003, s. 139). Przewidywanie psychiki rynku (ocenę niepewności) nazywa spekulacją. Jak wskazuje, przedsiębiorczość jest następstwem drzemiących w człowieku zwierzęcych instynktów, a przedsiębiorcy jedynie udają, że kierują nimi skrupulatne analizy. Przedsiębiorczość jest korzystna dla społeczeństwa jedynie w sytuacjach, gdy kalkulacje uzupełnia zwierzęcy instynkt. Pozwala on odsunąć myśli o porażce. Podstawowym czynnikiem determinującym ożywienie gospodarcze jest atmosfera polityczno-społeczna, w której funkcjonuje przeciętny przedsiębiorca (Keynes 2003). 
Współcześnie uznanym kryterium identyfikacji przedsiębiorcy i przedsiębiorczości jest innowacyjność. Podejście to zainicjowane zostało teorią przedsiębiorczości J. Schumpetera i następnie rozwinięte przez liczne grono ekonomistów. Czynnikiem konstytuującym przedsiębiorcę $w$ teorii J. Schumpetera jest realizowanie nowych kombinacji czynników produkcji i w konsekwencji tworzenie nowej wiedzy. Funkcja ta musi zawsze współistnieć z pozostałymi rodzajami działalności realizowanej przez podmiot gospodarczy. Przedsiębiorca schumpeterowski jest przedsiębiorcą jedynie w okresie tworzenia nowej wiedzy (Schumpeter 1960). Schumpeterowska teoria przedsiębiorczości spowodowała zmianę zarówno w sposobie tworzenia wiedzy, jak i stawianych wobec niej oczekiwań. Nowa wiedza przez przedsiębiorcę tworzona jest we współpracy z ośrodkami naukowo-badawczymi, od których oczekuje się "produkcji wiedzy". Tradycyjny system badań naukowych stał się niewydolny i został zastąpiony aplikacyjnym modelem wytwarzania wiedzy. Produkowana wiedza jest wynikiem ścierania się potrzeb, interesów i specyfikacji zaangażowanych podmiotów (Pohulak-Żołędowska 2013). Badania prowadzone są wyłącznie nad tym, co może podlegać komercjalizacji. Zamierają niekomercyjne dziedziny nauki. Retoryczne pozostają pytanie: $\mathrm{W}$ jakim zakresie obserwowane procesy prowadzą do zniszczenia nauki podporządkowanej interesom przemysłu oraz czy "produkowana wiedza” jest wiedzą w jej filozoficznym rozumieniu wskazywanym przez Platona i Arystotelesa? Zwrócenia uwagi wymaga sytuacja, w której na znaczenie sektora nauki dla rozwoju gospodarczego oraz zgodny z porządkiem naturalnym proces powstawania i wykorzystywania wiedzy wskazywał już J.B. Say. „Uczeni uczestniczą w produkcji, oddając na jej usługi wiedzę o prawach i ciałach przyrody, które następnie przedsiębiorcy przemysłowi wykorzystują na użytek człowieka" (Say 1960, s. 894).

Koncepcją współistniejącą z podejściem schumpeterowskim jest koncepcja identyfikacji przedsiębiorczości według kryterium umiejętności i sposobu zarządzania organizacją, przedstawiona w pracach W. Gartnera i H. Stevensona. W. Gartner przedsiębiorczość definiuje jako proces tworzenia organizacji. W definiowaniu przedsiębiorcy wyróżnia podejście behawioralne oraz zorientowane na cechy. W podejściu behawioralnym wskazuje konieczność analizowania przedmiotu działalności przedsiębiorcy. Przedsiębiorcą jest ten, kto tworzy organizację. W podejściu zorientowanym na cechy przedsiębiorca jest szczególnym 
typem osobowości, stałym stanem bytu. W odróżnieniu od podejścia schumpeterowskiego przedsiębiorca W. Gartnera jest przedsiębiorcą na zawsze (Gartner 1989). H. Stevenson dokonuje rozróżnienia pomiędzy zachowaniami przedsiębiorczymi i zarządzaniem. Przedsiębiorczość definiuje jako podejście do zarządzania, w którym poszukuje się i wykorzystuje szanse niezależnie od kontrolowanych zasobów. Celem zarządzającego jest najefektywniejsze wykorzystanie posiadanych zasobów. Zachowania determinują czynniki biznesowe i środowiskowe. Działania przedsiębiorcy napędzają możliwości istniejące w otoczeniu. Każda szansa jest istotna. Dla zarządzającego istotne są wyłącznie szanse odnoszące się do posiadanych zasobów. Przedsiębiorca jest zorientowany na działanie. Równie szybko angażuje się w działanie, jak i z niego się wycofuje. Zarządzający mają skłonność do podejścia analitycznego. Podejmowane przez nich decyzje są wynikiem analizy wielokryterialnej, wynegocjowanych strategii i działań minimalizujących ryzyko (Brown, Davidsson, Wiklund 2001).

\section{Przedsiębiorczość przyszłości}

Ewolucja pojęcia oraz wskazywanej roli przedsiębiorczości w rozwoju społeczno-gospodarczym będzie także następowała w przyszłości. Proces globalizacji stał się zalążkiem nowej formy przedsiębiorczości nazwanej przedsiębiorczością międzynarodową. Forma ta odegra kluczową rolę w kształtowaniu globalnego ładu społeczno-gospodarczego. Analiza postaw globalnych przedsiębiorstw pozwala twierdzić, że kolejnym etapem ewolucji przedsiębiorczości będzie przejmowanie przez przedsiębiorców tradycyjnych funkcji państwa i Kościoła. Należy oczekiwać ze strony przedsiębiorstw globalnych roszczenia sobie prawa do określania zasad życia społecznego, kształtowania systemu wartości, definiowania pojęć dobra i zła czy wprowadzania globalnej kontroli zgodności zachowań jednostki z systemami wartości organizacji. Niewątpliwie przejmowanie przez globalnych przedsiębiorców kontroli nad kolejnymi sferami życia może skutkować zniszczeniem wolnego rynku, konkurencji i w konsekwencji upadkiem kapitalizmu.

Uzasadnieniem dla powyższego twierdzenia jest analiza aktualnie podejmowanych działań przez firmy takie jak Facebook, Google, YouTube, Twitter w zakresie cenzurowania dopuszczanych do rozpowszechniania za ich pośrednictwem treści. Cenzurowaniu podlegają treści nienaruszające obowiązującego prawa, lecz jedynie kontestujące zachodzące 
procesy społeczne, polityczne i gospodarcze. Szczególną uwagę zwraca wystąpienie T. Cooka, dyrektora zarządzającego Apple Inc., który stwierdził: „W Apple nie boimy się mówić, że nasze wartości kierują naszymi decyzjami o wyborze działania. Wierzę, że najświętszą rzeczą, którą każdy z nas otrzymuje, jest nasz osąd, nasza moralność, nasze własne wrodzone pragnienie oddzielenia dobra od zła. Wybór odłożenia odpowiedzialności w momencie próby jest grzechem"3. W wypowiedzi tej jednoznacznie odrzucone zostaje wynikające z prawa naturalnego pojęcie dobra i zła na rzecz systemu wartości, którym kieruje się organizacja. Organizacja w sposób bezwzględny podejmuje próby narzucenia własnego systemu wartości globalnej populacji. Odrzucając zarazem - w ramach prowadzonej walki z wszelkimi formami dyskryminacji - wszelkie „inne" systemy wartości, w szczególności zaś system wartości oparty na Dekalogu.

Jednocześnie globalne przedsiębiorstwa tworzą narzędzia kontroli społeczeństw. Do współpracy nad systemem globalnej kontroli poprzez system uniwersalnej cyfrowej tożsamości przyznały się Microsoft oraz Mastercard 4 . Aktualnie osiem firm prowadzi badania nad systemami oceny wiarygodności obywateli. Systemy obejmują czarne listy, w ramach których gromadzone są informacje o niepożądanych i/lub niezgodnych z prawem zachowaniach poszczególnych obywateli, informacja finansowa oraz informacja o zachowaniach społecznych, w tym kontaktach z innymi ludźmi. Umieszczenie na czarnej liście skutkuje ograniczeniem lub wykluczeniem jednostki z życia społeczno-gospodarczego. O efektywności budowanych narzędzi kontroli społeczeństwa oraz zagrożeń z nich wynikających świadczy to, że system oceny wiarygodności obywateli działający w Chinach uniemożliwił osobom kontrolowanym odbycie 11,14 mln lotów samolotem oraz 4,25 mln przejazdów szybkimi pociągami ${ }^{5}$.

3.

Tim Cook's message to hatemongers: 'You have no place on our platforms', www.cnbc.com/2018/12/04/apple-ceo-tim-cook-says-hate-has-no-place-on-techplatforms-at-adl.html; Apple's CEO Suggests It's 'A Sin' To Not Ban People From Platforms, www.dailywire.com/news/38991/watch-apples-ceo-suggests-its-sin-not-ban-people-ryansaavedra [dostęp 6.12.2018].

4. Mastercard, Microsoft Join Forces to Advance Digital Identity Innovations, newsroom.mastercard.com/press-releases/mastercard-microsoft-join-forces-to-advancedigital-identity-innovations [dostęp 6.12.2018].

5. System oceny obywateli w Chinach powstrzymał już ludzi od $11 \mathrm{mln}$ lotów i $4 \mathrm{mln}$ podróży pociągiem, businessinsider.com.pl/lifestyle/podroze/system-oceny-obywateli-w-chinachefekty-dzialania/7yl1phz [dostęp 1.12.2018]. 


\section{Podsumowanie i wnioski}

Pojęcia przedsiębiorcy i przedsiębiorczości ukształtowały się po rewolucji przemysłowej. Podlegały one ewolucji w następstwie powstawania kolejnych szkół myśli ekonomicznej. Zmianom podlegała także wskazywana przez naukę rola przedsiębiorczości w rozwoju społeczno-gospodarczym. Obserwowane procesy zachodzące w sferze realnej pozwalają twierdzić, że przedsiębiorczość będzie odgrywała także istotną rolę w przyszłości. Działania globalnych przedsiębiorstw mające na celu przejmowanie funkcji należnych państwom i Kościołowi wymagają nieustannego podejmowania przez władze publiczne działań na rzecz ograniczania aktywności przedsiębiorstw do sfery gospodarczej. 


\section{Bibliografia}

$\rightarrow$ Białasiewicz, M. (2008), Przedsiębiorczość - pożq̨dana kompetencja, "Studia i Prace Wydziału Nauk Ekonomicznych i Zarządzania", Uniwersytet Szczeciński, nr 1, s. 7-16.

$\rightarrow$ Brown, T., Davidsson, P., Wiklund, J. (2001), An Operationalization of Stevenson's Conceptualization of Entrepreneurship as Opportunity - based Firm Behavior, "Strategic Management Journal”, nr 22 (10), s. 953-968.

$\rightarrow$ Butler, E. (2010), Ludwig von Mises. Kompendium myśli ekonomicznej, Warszawa: Instytut Globalizacji.

$\rightarrow$ Cantillon, R. (1959), Essay on the nature of trade in general, London: Frank Cass and Co, www.econlib.org/library/NPDBooks/Cantillon/cntNT.html?chapter_num=9\#book-reader [dostęp 9.10.2018].

$\rightarrow$ Gartner, W.B. (1989), "Who is an Entrepreneur?" is the Wrong Question, "Entrepreneurship Theory and Practice", Vol. 13, Issue: 4, s. 47-68.

$\rightarrow$ Hebert, R.F., Link, A.N. (2011), A History of Entrepreneurship, Reviewed By K.V. Nagarajan, „International Journal of Business and Social Science”, Vol. 2, No 9 [Special Issue - May 2011].

$\rightarrow$ Keynes, J.M. (2003), Ogólna teoria zatrudnienia, procentu i pieniq̨dza, Warszawa: Wydawnictwo Naukowe PWN.

$\rightarrow$ Knight, F.H. (1964), Risk, uncertainty and profit, "Reprints of economic classic”, Augustus M. Kelley, Bookseller, New York 1964, mises.org/sites/default/files/ Risk,\%20Uncertainty,\%20and\%20Profit_4.pdf [dostęp 9.10.2018].

$\rightarrow$ Rothbard, M.N. (2011), Richard Cantillon - ojciec współczesnej ekonomii, mises. pl/blog/2011/02/02/rothbard-richard-cantillon-ojciec-wspolczesnej-ekonomii [dostęp 9.10.2018].

$\rightarrow$ Say, J.B. (1960), Traktat o ekonomii politycznej, Warszawa: PWN.

$\rightarrow$ Schumpeter, J.A. (1960), Teoria rozwoju gospodarczego, Warszawa: PWN.

$\rightarrow$ Pohulak-Żołędowska, E. (2013), Miejsce nauki w kreowaniu innowacji we współczesnych gospodarkach, "Studia Ekonomiczne/Uniwersytet Ekonomiczny w Ka- 
towicach", nr 139, „Współczesne problemy ekonomiczne: polityka państwa a proces globalizacji". 


\section{Netografia}

$\rightarrow$ Mastercard, Microsoft Join Forces to Advance Digital Identity Innovations, newsroom.mastercard.com/press-releases/mastercard-microsoft-join-forces-to-advance-digital-identity-innovations (dostęp: 6.12.2018).

$\rightarrow$ Psychologiczne aspekty przedsiębiorczości, Forum Współpracy Małego i Dużego Biznesu, forumbiznesu-zpp.pl/aktualnosci/psychologiczne-aspekty-przedsiebiorczosci (dostęp: 30.11.2018).

$\rightarrow$ System oceny obywateli w Chinach powstrzymał już ludzi od $11 \mathrm{mln}$ lotów i $4 \mathrm{mln}$ podróży pocig̨giem, businessinsider.com. pl/lifestyle/podroze/system-oceny-obywateli-w-chinach-efekty-dzialania/7yl1 phz (dostęp: 1.12.2018).

$\rightarrow$ Tim Cook's message to hatemongers: 'You have no place on our platforms', www.cnbc.com/2018/12/04/apple-ceo-tim-cook-says-hate-has-no-place-on-tech-platforms-at-adl.html; Apple's CEO Suggests It's 'A Sin' To Not Ban People From Platforms, www.dailywire.com/news/38991/watch-apples-ceo-suggests-its-sin-not-ban-people-ryan-saavedra (dostęp: 6.12.2018). 